\title{
The effects of auditor switching towards abnormal return in manufacturing company
}

\author{
Filmiar Yunida Nawangsari and Iswajuni Iswajuni \\ Department of Accounting, \\ Universitas Airlangga Fakultas Ekonomi dan Bisnis, Surabaya, Indonesia
}

\begin{abstract}
Purpose - The purpose of this paper is to examine the effects of simultaneous and partial auditor switching toward the abnormal return of manufacturing companies listed in Indonesia Stock Exchange between 2009 and 2012.

Design/methodology/approach - Auditor switching is divided into some types: lateral Big 4 to Big 4 (B4B4), lateral non Big 4 to non Big 4 (NB4NB4), cross-up (CU) and cross-down. The abnormal return is measured with a market-adjusted model. In this study, company size is used as the control variable and is measured using the natural logarithm of the total assets (LnTA) and return on equity. Multiple linear regression is used for analysis with significant value $a=5$ percent. The hypotheses were tested using $f$-test and $t$-test. Findings - The result shows that simultaneous auditor switchings affect the abnormal return. In partial auditor switching, only $\mathrm{CU}$ switch has effects on the abnormal return.
\end{abstract}

Originality/value - This study provides additional literature on the effect of auditor switching, especially on an abnormal return.

Keywords Abnormal return, Auditor switching, Company size

Paper type Research paper

\section{Introduction}

Independence of public accounting is vital in auditing profession. One factor affecting the auditor's independence is the length of the relationship the auditors have with their clients (Institut Akuntan Publik Indonesia, 2011). Professional Standards for Public Accountant (Standar Profesional Akuntan Publik) section 290.153 indicates that if a similar senior public accounting firm is hired by one similar client for relatively long period of time, this relationship will threaten the auditor's independence. Therefore, the regulation related to auditor switching is made. The government has regulated the switch of auditor by releasing the Regulation of Minister of Finance of the Republic of Indonesia Number 17/PMK.01/2008 on the obligation to switch the public accounting firm after auditing for six consecutive years, and to switch a public accountant after auditing for three consecutive years (Kementerian Keuangan, 2008).

Sumadi (2010) and Junaidi et al. (2013) argue that auditor switching can be categorized into two: real auditor switching and artificial auditor switching. Real auditor switching is when a company switches its public accounting firm with another one from other affiliation, whereas artificial auditor switching is when a company uses a similarly affiliated public accounting firm, but still meets the requirements stated in the Regulation of Minister of Finance Number 17/PMK.01/2008 that a public accounting firm is counted as different firm

\section{JEL Classification - L6, M42}

(C) Filmiar Yunida Nawangsari and Iswajuni Iswajuni. Published in Asian Journal of Accounting Research. Published by Emerald Publishing Limited. This article is published under the Creative Commons Attribution (CC BY 4.0) licence. Anyone may reproduce, distribute, translate and create derivative works of this article (for both commercial and non-commercial purposes), subject to full attribution to the original publication and authors. The full terms of this licence may be seen at http:// creativecommons.org/licences/by/4.0/legalcode

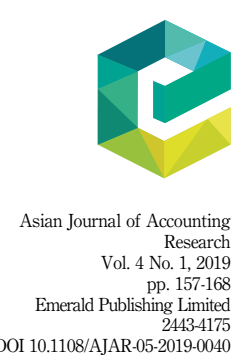

Received 24 May 2019

\section{(1)}

(1) 
AJAR

4,1

158

when the number of the partner in the latter firm is less than 50 percent of that in the former firm (Sumadi, 2010). Auditor switching can also be classified into three: lateral auditor switching (switching accounting firm with another similar size firm); cross-up (CU) auditor switching (switching smaller accounting firm with a larger firm); and cross-down (CD) auditor switching (switching larger accounting firm with a smaller firm).

There are debating arguments related to auditor switching that encourage further research in areas including factors contributing to auditor switching and its impacts. Several previous studies analyzing the effects of auditor switching on the abnormal return showed different results. Research conducted by Soeprihadi and Adiwibowo (2010), Stunda (2012), Knechel et al. (2007) and Eichenseher et al. (1989) generally highlighted that CU auditor switching positively affected the abnormal return, while $\mathrm{CD}$ auditor switching negatively affected the abnormal return. Other research by Chang et al., (2010), Diaz (2009) and Dunn et al. (1999) resulted that auditor switching negatively affected the abnormal return. In addition, Nichols and Smith (1983) found that there was no significant influence between auditor change and stock. The inconsistent research findings in many research related to auditor switching have encouraged the writer to further research the influence of auditor switching on, particularly, the abnormal return.

This research aims at analyzing how investors react and respond the switch of the public accounting firm by the manufacturing companies listed in Indonesia Stock Exchange between 2009 and 2012. This research has similarity with that of Stunda (2012) in terms of dividing the auditor switching into lateral, CU, and CD auditor switchings. Auditor switching as a variable is divided into three types to help better identify the effects of each type by considering the switch as well as the firm size. This research uses the firm size and return on equity (ROE) as the control variables, so that the possible effects of auditor switching on the abnormal return will not be affected by other factors other than the ones used in the research.

The research shows that simultaneous auditor switchings affect the abnormal return as the dependent variable. Partial auditor switching, particularly the CU auditor switching, affects the abnormal return. The result of this research is expected to be taken as one of the considerations for the management of the company prior to switching the public accounting firm, and this can also be used to maintain the independency and objectivity of the auditor.

\section{Literature review and hypothesis}

\section{Signaling theory}

Leland and Pyle (cited in Scott, 2012, p. 475) state that company executives with more company related information tend to inform the potential users from which the company may increase its values by signaling through their annual reports. When investors receive good signal mentioned in the annual financial report, they will positively respond to it. In contrast, the investors will respond negatively when bad signal is perceived. The changes of the response can be observed through the changes of the stock price; in this particular case, the changes will be measured using the abnormal return.

\section{Auditor switching}

Stunda (2012) and Eichenseher et al. propose the classification of auditor switching into three: lateral, CU and CD auditor switchings. Lateral auditor switching is the switch from the auditor or the public accounting firm to a new similar size auditor or a public accounting Firm. Srimindarti (2006) argues that one main reason for a company to switch its public accounting firm is the high fee for CU auditor switching that is a switch to a new larger firm of public accounting. Smith (cited in Sumadi, 2010) proposes that a company involved in expanding activities expects to receive positive responses from investors by switching auditor with the larger and more settled public accounting firm. $\mathrm{CD}$ auditor switching is a 
switch to a new smaller public accounting firm. Sinarwati (2010), in her research, shows that management change and financial difficulty may affect decision to switch auditors and accounting firms.

Sumadi (2010) proposes several reasons for company to undergo auditor switching. Among the reasons are the management receives unqualified audit opinion reports; the new company management tends to find a firm with equivalent reports and accounting policies; the management is being involved in expanding activities; or the management is facing financial problems. Several factors affecting auditor switching are shopping opinion, audit fee, characteristics of public accounting firm, unsatisfactory service from public accounting firm and the preference of the stock holders (Stefaniak, et al., 2009).

\section{Abnormal return}

Abnormal return or known as excess return is the difference between the realized and the expected return (Jogiyanto, 2012). A positive abnormal return occurs when the realized return is higher than the expected return, and vice versa. Abnormal return is considered as one of indicators of market response toward information. Jogiyanto (2012) proposes three models to identify expected return: mean-adjusted model, market model and market-adjusted model. The formula for calculating the abnormal return will be obtained after knowing the formula for the realized return.

Company size. The company size indicates categorization of company into a small or large company by measuring the sales, the capital, or the total assets owned. Djam'an et al. (2011) uses total assets to assess the size of the firm. It is shown that the total assets provide positive and significant influence on the abnormal return. This is in contrast with what Diaz (2009) finds, that is, the size of the company does not significantly influence the abnormal return.

\section{Return on equity (ROE)}

$\mathrm{ROE}$ is the ratio used to assess the ability of the company to earn profit based on certain capital stock (Hanafi and Halim, 2009). This ratio measures the level of capital return of the company. Kastutisari and Dewi (2012), in their research, conclude that ROE affects the abnormal return. A company with high ROE will encourage investors to invest in that company. The higher the investment invested, the higher the stock price observed in the abnormal return.

The effects of lateral, $C U$ and $C D$ switchings, company size and ROE on the abnormal return. The investors will react to financial and non-financial information published by the company. Lateral, CU and CD auditor switchings can be seen from the auditor report, and the information related to the company size as well as the ROE will be responded by the investors. Their responses can be seen in the changes of stock price that will be measured with the abnormal return:

H1. Lateral, CU, and CD auditor switchings, company size and ROE simultaneously affect the abnormal return.

The effect of Big 4 to Big 4 lateral auditor switching on abnormal return. The switch from a Big 4 to Big 4 accounting firm is taken since the company has accustomed to be the client of the Big 4 accounting firm as well as to maintain the good image of the company. Big 4 to Big 4 lateral auditor switching may affect positively the abnormal return, particularly when the switch is caused by the expanding activities of the company supported with good work performance as expected by the investors. Contrarily, when the company shows less satisfying work performance, then the switch will affect negatively the abnormal return:

H2. Big 4 to Big 4 lateral auditor switching affects the abnormal return. 
AJAR

4,1

160

The effect of non Big 4 to non Big 4 lateral auditor switching on the abnormal return. A company that switches its accounting firm from non Big 4 to non Big 4 may experience negative impact, especially when the switch is resulted from a financial distress and conflict with the previous auditor. The switch as an effort to maintain auditing fee may have positive impacts, especially when the company is allocating its cash for other priorities to increase the value of the company:

H3. Non Big 4 to non Big 4 lateral auditor switching affects the abnormal return.

The effect of $C U$ auditor switching on the abnormal return. There are reasons that affect a company to switch its accounting firm from a non Big 4 to a Big 4 Auditing firm. One of the reasons is that the firm expects a positive response from the investors. Investors exposed to information of auditor switch to the Big 4 accounting firm will recognize the change as a positive signal that leads to an assumption of good work performance of the company. However, CU auditor switching can affect negatively the abnormal return, particularly if the switch aims at covering the conflict between the management and the auditor. Furthermore, this practice may negatively influence negatively the investors, particularly when the company frequently switches its accounting firms:

H4. CU auditor switching affects the abnormal return.

The effect of $C D$ auditor switching on the abnormal return. $\mathrm{CD}$ auditor switching may positively or negatively affect the abnormal return. During the post-SOX period, there were some non Big 4 accounting firms that offered better service to its clients, and this resulted in qualified auditing opinion normally offered by Big 4 firms. However, some investors may take the information as a bad signal, indicating a practice of opinion shopping in which what is being reported is not similar to that of the actual situation. Opinion shopping is an effort a company takes to get a better audit opinion:

H5. CD auditor switching affects the abnormal return.

\section{Conceptual framework}

In this research, the conceptual framework is the effect of auditor switching on the abnormal return. Auditor switching variable will be divided into three, namely, lateral, $\mathrm{CU}$ and $\mathrm{CD}$ auditor switchings. Lateral auditor switching is divided into two: Big 4 to Big 4 and non Big 4 to non Big 4. Abnormal return is the difference between realized return and expected return, and in measuring the expected return, a market-adjusted model is used. This research also uses the size of the company and $\mathrm{ROE}$ as the control variables to limit the influence of other factors on the auditor switching (Figure 1).

\section{Research method}

\section{Approaches and data}

This research used a quantitative approach to test the hypotheses. This approach was adopted since all the data are measurable, and the result can be generalized (Anshori and Iswati, 2009). The data used were unbalanced panel data as the number of companies observed was different yearly. Panel data are the combination of time series and cross-sectional data (Gujarati and Porter, 2013). To obtain those data, secondary data were used. Following are the data and its sources used in this research:

(1) Data of auditor switching were obtained from the auditor report documented in each company's annual financial report published on the website of Indonesia Stock 

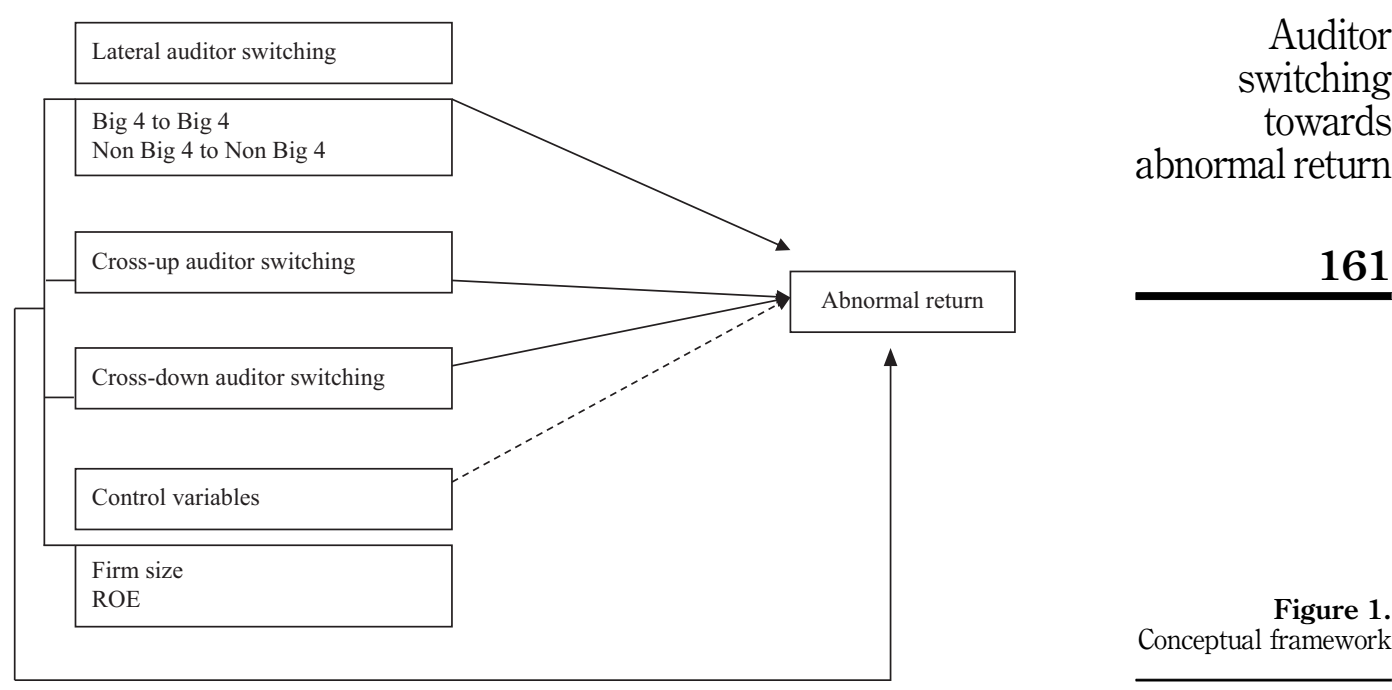

Exchange (www.idx.co.id) between 2009 and 2012. The data were also taken from the factbook published by Indonesia Stock Exchange.

(2) Data of stock prices were obtained from finance.yahoo.com

\section{Population and samples}

The population of this research was manufacturing companies listed in Indonesia Stock Exchange between 2009 and 2012. This type of company was selected as the population since they have more sectors compared to other types of company. In addition, manufacturing companies were more involved and dominating in cases related to auditing switch. The period between 2009 and 2012 was preferred to respond to the Regulation of the Minister of Finance Number 17/PMK 0.1/2008, released by the Ministry of Finance that enquires the companies to switch their public accounting firms after six consecutive auditing years. The research duration was expanded to 2012 to cover the occurrence of all types of auditor switching mentioned above.

The samples were selected using the purposive sampling method in which the selected samples had to match with the set criteria as following:

(1) the manufacturing companies were listed in Indonesia Stock Exchange between 2009 and 2012;

(2) the manufacturing companies were not delisted during the period of 2009 and 2012;

(3) those companies undertook auditor switching during the period of 2009 and 2012; and

(4) those companies were supported with complete data available in IDX databases during the period of 2009 and 2012.

\section{The definition of operational variables}

The dependent variable of this research is the abnormal return. Jogiyanto (2012) defines abnormal return as the difference between realized return and expected return (the return expected by the investors). Realized return is the real return that actually happens at specific 
AJAR

4,1

time $t$. Expected return is the return expected from the future investment. The steps and formula in calculating the abnormal returns are presented next.

Calculating realized return

$$
R_{i, t}=\frac{P_{i, t}-P_{i, t-1}}{P_{i, t-1}}
$$

Where $R_{i, t}$ is the realized return of security $i$ at time $t ; P_{i, t}$ is the stock price of security $i$ in December of auditor report; and $P_{i, t-1}$ is the stock price of security $i$ in December of financial report.

This research used the monthly stock price in December. $t$ index is the year in which auditor report was published, while $t-1$ is the year of the financial report.

Calculating the expected return

$$
\begin{gathered}
E\left[R_{i, t}\right]=R M_{i, t} \ldots, \\
R M_{i, t}=\frac{I H S G_{t}-I H S G_{t-1}}{I H S G_{t-1}},
\end{gathered}
$$

where $\mathrm{E}\left[R_{i, t}\right]$ is the expected return of security $i$ at time $t ; R M_{i, t}$ is the market return of security $i$ at time $t$; IHSG $G_{t}$ is the composite stock price index in December of auditing report; and $I H S G_{t-1}$ is the composite stock price index in December of financial report.

Calculating abnormal return

$$
A R_{i, t}=R_{i, t}-E\left[R_{i, t}\right]
$$

where $A R_{i, t}$ is the abnormal return of security $i$ at time $t ; R_{i, t}$ is the realized return of security $i$ at time $t$; and $E\left[R_{i, t}\right]$ is the expected return of security $i$ at time $t$. $t$ index in the formula above refers to the year the auditing report was published by an independent auditor, while $t-1$ index refers to the year when the financial report was written by the company.

The independent variables of this research are the three types of auditor switching as follows:

(1) Lateral auditor switching:

- Big 4 to Big 4: the switch of this type was measured using dummy variables by scoring 1 for companies switching from Big 4 to Big 4 firms, and scoring 0 for companies switching to firms other than Big 4 to Big 4 .

- Non Big 4 to non Big 4: the lateral auditor switching from non Big 4 to non Big 4 firms was measured using a dummy variable by scoring 1 for companies switching from non Big 4 to non Big 4 firms, and scoring 0 for companies switching to firms other than non Big 4 to non Big 4.

(2) CU auditor switching: CU auditor switching would also be measured using dummy variable by scoring 1 for companies switching from non Big 4 to Big 4 firms, and scoring 0 for companies undertook other than CU auditor switching.

(3) CD auditor switching: CD auditor switching was also measured using dummy variable by scoring 1 for companies switching from Big 4 to non Big 4 firms, and scoring 0 for companies undertook other than $\mathrm{CD}$ auditor switching.

The control variables of this research were the company size and the ROE. The total assets were used to measure the company size at the end the year. To calculate the influence of the company size on the control variables, the natural logarithm of the total assets was used. 
$\mathrm{ROE}$ is the ratio used to assess the ability of the company to earn profit from certain capital stock (Hanafi and Halim, 2009). The ROE value can be calculated using the formula as follows (Gibson, 2009):

$$
R O E=\frac{\text { Net Income-Dividends on Preferred Stock }}{\text { Average Total Equity }} .
$$

Auditor switching towards abnormal return

Data analysis

The data were analyzed statistically using SPPS program v.18. Multiple linear regression technique was used with the ordinary least square method. The regression model can be seen in the following formula:

$$
A R_{i t}=a+\beta_{1} B 4 B 4_{i t}+\beta_{2} N B 4 N B 4_{i t}+\beta_{3} C U_{i t}+\beta_{4} C D_{i t}+\beta_{5} \operatorname{Ln} T A_{i t}+\beta_{6} R O E_{i t}+\varepsilon_{i t},
$$

where $A R_{i, t}$ is the abnormal return of the manufacturing company; $\alpha$ is the intercept; $B 4 B 4_{i, t}$ is Big 4 to Big 4 lateral auditor switching; $N B 4 N B 4_{i, t}$ i non Big 4 to non Big 4 lateral auditor switching; $C U_{i, t}$ is cross-up auditor switching; $C D_{i, t}$ is cross-down auditor switching; $\operatorname{Ln} T A_{i, t}$ is the natural log of the total assets; $R O E_{i, t}$ is the return on equity; and $\varepsilon_{i t}$ I the error measurement for the company.

\section{Hypothetical tests}

(1) A simultaneous test $(f)$ was conducted to identify the effect of several independent variables simultaneously on the dependent variables (Ghozali, 2006). The criteria adopted for simultaneous test are:

- if fcount $>$ ftable, then $H 1$ is accepted ( $\alpha=5$ percent); and

- if fcount $<$ fable, then $H 1$ is rejected ( $\alpha=5$ percent).

(2) A partial test $(t)$ indicates to what extent the effect of independent variables partially affect the dependent variable (Ghozali, 2006). The partial test was conducted by comparing the significance of $t$-value from the test result and the value used in this research. The criteria for partial test are presented as follows:

- if the significance $t$-value of each variable obtained from the test is $<5$ percent, then the independent variables partially affect the dependent variable; and

- if the significance $t$-value of each variable obtained from the test is $>5$ percent, the independent variables do not partially affect the dependent variable.

\section{Result and discussion}

Description of the research object

There were 109 manufacturing companies, selected using a purposing sampling technique, involved in this research (Table I).

\section{Descriptive statistical analysis}

Below are the descriptive statistical analyses of each variable of this research using SPSS program v.18.

Based on Table II, each variable can be described as follows:

(1) Auditor switching: the manufacturing companies involved mostly switched from non Big 4 to non Big 4 public accounting firms, and very few of them undertook CD auditor switching. The mean of B4B4 auditor switching is 0.3 , which means that 
AJAR

4,1

\section{4}

30 percent of the total manufacturing companies involved switched their accounting firms from Big 4 to Big 4 firms. The mean of NB4NB4 auditor switching is 0.61, which means that 61 percent of the total manufacturing companies involved switched their accounting firms from non Big 4 to non Big 4 firms. The mean of CU auditor switching is 0.05 , which means 5 percent of the manufacturing companies involved switched their accounting firms from non Big 4 to Big 4 firms. The mean of $\mathrm{CD}$ auditor switching is 0.04 , which means that 4 percent of the total manufacturing companies involved switched their accounting firms from Big 4 to non Big 4 firms.

(2) Company size: this research used the natural logarithm of the total assets (LnTA) because the total assets of the company are very high. The highest LnTA value is 32.36, owned by Astra International Tbk in 2010, and the smallest LnTA is 23.08, owned by Alam karya Unggul Tbk in 2012. The overall value of LnTA of the companies is 27.65 .

(3) ROE: the research shows that the highest ROE is 129 percent, owned by Delta Dunia Petroindo Tbk (DOID) in 2011, while the lowest ROE equals -134.93 percent by ICTSI Jasa Prima Tbk (KARW) in 2012. The overall value of ROE of the companies involved is 6.15 percent.

(4) Abnormal return: the biggest rate of abnormal return is 18.5439 by Indospring Tbk in 2011, and the lowest rate is -1.16 , owned by Kertas Basuki Rachmat Indonesia Tbk in 2009. The overall rate of the abnormal return of the companies involved is 0.24 .

\section{Result and analysis}

This research adopted four classical assumption tests: normality test, multicollinearity test, heteroscedasticity test and autocorrelation test. It is concluded that normality assumption was fulfilled, there was no multicollinear and heteroscedasticitic data, and there was no autocorrelation between residual values.

\begin{tabular}{llcccc}
\hline No. & Criteria & 2009 & 2010 & 2011 & 2012 \\
\hline 1 & Listed manufacturing company & 139 & 136 & 139 & 140 \\
2 & Delisted manufacturing company & $(5)$ & $(1)$ & $(2)$ & $(1)$ \\
3 & Manufacturing company with no auditor switching & $(100)$ & $(76)$ & $(127)$ & $(114)$ \\
4 & Companies with incomplete data & $(8)$ & $(8)$ & $(1)$ & $(2)$ \\
& Research samples & 26 & 51 & 9 & 23 \\
& Overall samples & 109 & & & \\
\end{tabular}

Table I.

Sample criteria of research

\begin{tabular}{lccccc}
\hline & $n$ & Minimum & Maximum & Mean & SD \\
\hline B4B4 & 109 & 0 & 1 & 0.30 & 0.462 \\
NB4NB4 & 109 & 0 & 1 & 0.61 & 0.489 \\
CU & 109 & 0 & 1 & 0.05 & 0.210 \\
CD & 109 & 0 & 1 & 0.04 & 0.189 \\
LnTA & 109 & 23.08 & 32.36 & 27.57 & 1.52456 \\
ROE & 109 & -134.93 & 129 & 6.15 & 29.674875 \\
Abnormal return & 109 & -1.16 & 18.45 & 0.24 & 1.9657288 \\
\hline
\end{tabular}


Based on the multiple linear regression test presented on Table III, the equation of the regression can be formulated as following:

$$
A R=0.168+0.004 B 4 B 4-0.533 C U+0.340 C D+0.003 R O E-0.007 \operatorname{Ln} T A .
$$

The tcount on the table for Big 4 to Big 4 (B4B4) lateral auditor switching variable is 0.036 , with a significance value of 0.971 . This value is higher than the significance value of $\alpha=0.05$, and therefore $H_{0}$ is accepted and $H 2$ is rejected. In other words, the Big 4 to Big 4 (B4B4) lateral auditor switching does not affect the abnormal return. The tcount for CU auditor switching variable is -2.391 , with a significance value of 0,019 . This value is lower than the significance value of $\alpha=5$ percent, and thus $H_{0}$ is rejected and $H 4$ is accepted. In other words, CU auditor switching affects the abnormal return. The tcount for CD auditor switching variable is 1.365 , with a significance value of 0.175 . This value is higher than the significance value of $\alpha=0.05$ percent, and thus $H_{0}$ is accepted and $H 5$ is rejected. In other words, CD auditor switching does not affect the abnormal return. The tcount for the company size proxied with total assets, as the control variable, is -0.208 with significance value of 0.836 . This value is higher than the significance value of $\alpha=5$ percent, and thus it can be concluded that the company size does not affect the abnormal return. The tcount for the ROE, as the control variable, is 1.684 , with a significance value of 0.095 . This value is higher than the significance value of $\alpha=5$ percent, and thus it can be concluded that the company size does not affect the abnormal return.

Table IV indicates that the $f$ count value is 2.249 , with a significance value of 0.04 . This value is lower than the significance value of $\alpha=5$ percent, and thus it is concluded that all

\begin{tabular}{|c|c|c|c|c|c|c|c|c|c|}
\hline \multirow[b]{2}{*}{ Model } & & \multicolumn{2}{|c|}{$\begin{array}{l}\text { Unstandarized } \\
\text { coefficients }\end{array}$} & \multirow{2}{*}{$\begin{array}{c}\text { Standarized } \\
\text { coefficients } \\
\beta\end{array}$} & \multirow[b]{2}{*}{$T$} & \multirow[b]{2}{*}{ Sig. } & \multicolumn{2}{|l|}{$\begin{array}{l}\text { Collinearity } \\
\text { statistics }\end{array}$} & \\
\hline & & $B$ & $\mathrm{SE}$ & & & & Tolerance & $\mathrm{VIF}$ & \\
\hline \multirow[t]{4}{*}{ Variable independent } & (Constant) & 0.168 & 0.983 & & 0.171 & 0.846 & & & \\
\hline & B4B4 & 0.004 & 0.117 & 0.004 & 0.036 & 0.971 & 0.752 & 1.330 & \\
\hline & $\mathrm{CU}$ & -0.533 & 0.223 & -0.231 & -2.391 & 0.019 & 0.965 & 1.036 & \\
\hline & $\mathrm{CD}$ & 0.340 & 0.249 & 0.132 & 1.365 & 0.175 & 0.956 & 1.046 & Table III. \\
\hline \multirow[t]{2}{*}{ Variable control } & LnTA & -0.007 & 0.036 & 0.036 & -0.208 & 0.836 & 0.758 & 1.319 & Multiple linear \\
\hline & ROE & 0.003 & 0.002 & 0.171 & 1.684 & 0.095 & 0.877 & 1.140 & regression analysis \\
\hline
\end{tabular}

\begin{tabular}{|c|c|c|c|c|}
\hline Variables & $T$ & Sig. & Remark & \\
\hline \multicolumn{5}{|c|}{ Independent variables } \\
\hline B4B4 & 0.036 & 0.971 & $H 2$ rejected & \\
\hline $\mathrm{CU}$ & -2.391 & 0.019 & H4 accepted & \\
\hline $\mathrm{CD}$ & 1.365 & 0.175 & $H 4$ rejected & \\
\hline \multicolumn{5}{|c|}{ Control variables } \\
\hline LnTA & -0.208 & 0.836 & No effect & \\
\hline $\mathrm{ROE}$ & 1.684 & 0.095 & No effect & \\
\hline$R$ & 0.331 & & & \\
\hline$R^{2}$ & 0.109 & & & \\
\hline Adjusted $R^{2}$ & 0.064 & & & \\
\hline$F$ & 2.249 & & & Table IV. \\
\hline Sig. $F$ & 0.040 & & $H 1$ accepted & Proof of hypotheses \\
\hline
\end{tabular}

Auditor switching towards abnormal return

165 
AJAR

4,1

166

independent variable of Big 4 to Big 4 (B4B4) lateral auditor switching, CU auditor switching and CD auditor switching, as well as the control variables, company size (LnTA) and the ROE, simultaneously affect the abnormal return as the dependent variable.

In table, it is seen that adjusted $R^{2}$ value is 0.064 . This denotes that the effect of such variables as Big 4 to Big 4 (B4B4) lateral auditor switching, CU auditor switching, CD auditor switching, company size (LnTA) and ROE on the abnormal return is 0.064 or 64 percent, while the rest 0.936 , or 93.6 percent, is affected by other variables such as earning per share (EPS), ROA, government announcement, political issues, national and international issues, funding announcement and others that are not part of this research.

The simultaneous effect of Big 4 to Big 4 lateral, CU, CD auditor switchings, company size and ROE on the abnormal return. The research shows that Big 4 to Big 4 lateral, CU, CD auditor switchings, company size and ROE simultaneously affect the abnormal return. This result is in line with the signal theory and it proves that Big 4 to Big 4 lateral, CU, CD auditor switchings, company size and ROE are all responded by the investors. The response from the investors explains that the information is considered by the auditors prior to the decision for investment. The findings of this research support the research finding of Dunn et al. (1999).

The effect of Big 4 to Big 4 lateral auditor switching on the abnormal return. The findings show that Big 4 to Big 4 lateral auditor switching does not affect the abnormal return. This can be explained with the fact that most switches undertaken are the partial switches (Junaidi et al., 2013). A partial rotation or switch refers to a condition as suggested by the government regulation that the company has switched its accounting firm and, therefore, the company and accounting firm relation does not exit. In fact, the company as the client and the accounting firm are essentially still in contact. This artificial auditor switch does not much affect the auditors as they belong to the same public accounting firm. This finding is similar to that of Stunda (2012).

The effect of $C U$ auditor switching on the abnormal return. The research demonstrates that CU auditor switching negatively affects the abnormal return. These negative impacts can be resulted from various reasons like the audit tenure and EPS. If the audit tenure is very short, then this may lead to suspicion among the investors. In contrast, when the tenure is longer than six consecutive years, then the investors might reconsider and question the independence of the auditor. In addition, the companies, involved in this research, that CU switched its accounting firms tended to decrease their EPS. This finding is similar to that of Diaz (2009), Chang et al. (2010) and Dunn et al., (1999).

The effect of $C D$ auditor switching on the abnormal return. The research shows $\mathrm{CD}$ auditor switching does not affect the abnormal return. This finding is in line with that of Nichols and Smith (1983). This strengthens the idea that CD auditor switching contributes very limited information in improving the abnormal return for company. This probably because the investors consider that non Big 4 accounting firms are as good as the Big 4 firms previously hired by the company. As a result, the switch does not affect the investors, which is reflected in the abnormal return.

The effect of company size on the abnormal return. The research demonstrates that the company size proxied with the total assets (LnTA) does not affect the abnormal return. This finding is similar to that of Diaz (2009). The investors might think that the amount of the total assets owned by a company not necessarily ensures the investors of a high return for their investment. These investors prefer other financial information, such as an increase or decrease rate return like EPS.

The effects of ROE on the abnormal return. The research shows that ROE does not affect the abnormal return. This finding is in contrast with that of Kastutisari and Dewi (2012). In their research, ROE affected the abnormal return. Many investors might consider ROE as 
the ability of the company to earn profit from the investment, and do not illustrate and predict the future prospect and development of the company. Thus, many investors neglect ROE during their investment decision making.

$\begin{array}{r}\text { Auditor } \\ \text { switching } \\ \text { towards } \\ \text { abnormal return } \\ \mathbf{1 6 7} \\ \hline\end{array}$

\section{Conclusion and the limitation of the research}

Several inferences can be obtained from this research: Big 4 to Big 4 (B4B4) lateral auditor switching, CU auditor switching and CD auditor switching, and other control variables such as company size (LnTA) and return in equity (ROE) simultaneously affect the abnormal return as the dependent variable; and, partially, CU auditor switching affects the abnormal return, while Big 4 to Big 4 (B4B4) lateral, CD auditor switchings, company size (LnTA) and ROE do not affect the abnormal return.

There are some limitations during the research: the indicator used to measure auditor switching is limited solely to the switch of the accounting firm and not to the public accountant, due to limited access to the related data; referring to the previous research, the auditor switching was measured through the auditor report found in the company's financial report as well as through the switch announcement published by the company in Indonesia Stock Exchange, while this research used only auditor report, considering that not all companies that switched their accounting firms announced their switches on Indonesia Stock Exchange.

\section{References}

Anshori, M. and Iswati, S. (2009), Metodologi Penelitian Kuantitatif., Universitas Airlangga, Surabaya.

Chang, H., Cheng, C.S.A. and Kenneth, R. (2010), "Market reaction to auditor switching from Big 4 to third-tier small accounting firms", A Journal of Practice \& Theory Auditing, Vol. 29 No. 2, pp. 83-114.

Diaz, M. (2009), “Analisis Reaksi Pasar Terhadap Pengumuman PergantianKantor Akuntan Publik”, Simposium Nasional Akuntansi XIII, Purwokerto.

Djam'an, N., Pagalung, G. and Tawakkal. (2011), "Pengaruh Informasi Laporan Arus Kas, Laba dan Size Perusahaan Terhadap Abnormal Return Saham Pada Perusahaan Manufaktur Yang Terdaftar Di Bursa Efek Indonesia”, available at: http://pasca.unhas.ac.id/jurnal/files/ ce6c75346eac5f3579b8abd47ac2eee1.pdf

Dunn, J., Hillier, D. and Marshall, A.P. (1999), "The market reaction to auditor resignations", Accounting and Business Research, Vol. 29 No. 2, pp. 95-108.

Eichenseher, J.W., Hagigi, M. and Shields, D. (1989), "Market reaction to auditor changes by OTC companies", Auditing: A Journal of Practice \& Theory, Vol. 9 No. 1, pp. 29-40.

Ghozali, I. (2006), Aplikasi Analisis Multivariate dengan Program SPSS, Badan Penerbit Universitas Diponegoro, Semarang.

Gibson, C. (2009), "Financial reporting \& analysis", South-Western Cengage Learning.

Gujarati, D. and Porter, D.C. (2013), Dasar-Dasar Ekonometrika, 5th ed., Salemba Empat, Jakarta.

Hanafi, M.M. and Halim, A. (2009), Analisis Laporan Keuangan, 4th ed., UPP STIM YKPN, Yogyakarta.

Institut Akuntan Publik Indonesia (2011), "Standar Profesional Akuntan Publik (SPAP) Pernyataan Standar Auditing No. 1, Standar Auditing Seksi 220", Salemba Empat, Jakarta.

Jogiyanto, H.M. (2012), Teori Portofolio dan Analisis Investasi, 7th ed., BPFE Yogyakarta, Yogyakarta.

Junaidi, H., Suwardi and Miharjo (2013), "Rotasi Semu dan Tenur Kantor Akuntan Publik (KAP) Pada Independensi”, Simposium NasionalAkuntansi XVI, Manado.

Kastutisari, S. and Dewi, N.H.U. (2012), "Pengaruh pengungkapan corporate social responsibility (csr) terhadap abnormal return”, Jurnal Akuntansi Perbanas, pp. 102-121.

Kementerian Keuangan (2008), "Peraturan Menteri Keuangan Republik Indonesia tentang Jasa Akuntan Publik Nomor: 17/PMK.01/2008”. 
AJAR

4,1

168

Knechel, W.R., Naiker, V. and Pacheco, G. (2007), "Does auditor industry specialization matter? Evidence from market reaction to auditor switches", Auditing: A Journal of Practice and Theory, Vol. 26 No. 1, pp. 19-45.

Nichols, D. and Smith, D. (1983), "Auditor credibility and auditor change", Journal of Accounting Research, Vol. 21 No. 2, pp. 534-544.

Scott, W.R. (2012), Financial Accounting Theory, 6th ed., Pearson Prentice Hall.

Sinarwati, N.K. (2010), "Mengapa Perusahaan Manufaktur Yang Terdaftar diBEI Melakukan Pergantian Kantor Akuntan Publik?”, Simposium Nasional Akuntansi XIII, Purwokerto.

Soeprihadi and Adiwibowo, A.S. (2010), "Analisis Reaksi Pasar Terhadap Pergantian Kantor Akuntan Publik Dan Opini Audit”, E-Journal Universitas Diponegoro, available at: http://eprints.undip.ac. id/29251/1/JURNAL_Dwi.pdf

Srimindarti, C. (2006), "Opini audit dan pergantian auditor: Kajian Berdasarkan Resiko, Kemampuan Perusahaan dan Kinerja Auditor", Fokus Ekonomi, Vol. 5 No. 1, pp. 64-76.

Stefaniak, C.M., Robertson, J.C. and Houston, R.W. (2009), "The cause and consequences of auditor switching: a review of the literature", Journal of Accounting Literature, Vol. 28, pp. 47-121.

Stunda, R. (2012), "Auditor switches in a post-sox environment, does the change in auditor mean a change in stock price?", Journal of Business and Behavioral Sciences, Vol. 24 No. 3, pp. 65-71.

Sumadi, K. (2010), "Mengapa Perusahaan Melakukan Auditor Switch?”, Jurnal Akuntansi dan Bisnis, Universitas Udayana, available at: http://download.portalgaruda.org/article.php?article=140 $94 \& \mathrm{val}=945$

\section{Further reading}

Ferguson, A., Lam, P. and Ma, N. (2018), "Market reactions to auditor switches under regulatory consent and market driven regimes", Journal of Contemporary Accounting and Economics, Vol. 14 No. 2, pp. 197-215.

Schneider, A. (2015), "Does information about auditor switches affect investing decisions?", Research in Accounting Regulation, Vol. 27 No. 1, pp. 39-44.

Schneider, A. (2017), "Is commercial lending affected by knowledge of auditor switches from Big 4 firms to regional firms?", Accounting Research Journal, Vol. 30 No. 2, pp. 153-170.

\section{Corresponding author}

Iswajuni Iswajuni can be contacted at: iswajuni@feb.unair.ac.id

For instructions on how to order reprints of this article, please visit our website: 